\title{
Autoimmune Hemolytic Anemia as a Novel Complication of COVID-19 Infection in Sanglah General Hospital Bali, Indonesia
}

\author{
I. Putu Surya Sujana ${ }^{1 *}$, Ni Putu Ayu Widiasari ${ }^{1}$, Ni Luh Putu Eka Arisanti ${ }^{1}$, Ida Bagus Ngurah Rai ${ }^{1}$, \\ Ni Made Renny Anggreni Rena ${ }^{2}$ \\ ${ }^{1}$ Department of Pulmonology, Faculty of Medicine, Udayana University, Bali, Indonesia; ${ }^{2}$ Department of Internal Medicine, \\ Faculty of Medicine, Udayana University, Bali, Indonesia
}

Edited by: Mirko Spirosk Citation: Sujana IPS, Widiasari NPA, Arisanti NLPE, Rai IBN, Rena NMRA. Autoimmune Hemolytic Anemia as a Novel Complication of COVID-19 Infection in Sangla General Hospital Bali, Indonesia. Open Access Maced Med Sci. 2020 Nov 16; 8(T1):509-513 Keywords: Autoimmune hemolytic anemia; Coronavirus disease-19; Corticosteroid ondence: I. Putu Surya Sujana, Departmen of Pulmonology, Faculty of Medicine, Udayana University, Bali, Indonesia. Phone: (+62) 81934379349. E-mail: sujanaiputusurya@gmail.com Received: 28-Sep-2020 Revised: 02-Nov-2020 Copyright: $\odot 2020$ : Pud: 06 Nov-2020

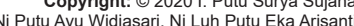

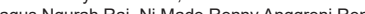
Funding: Publication of this article was financially ful by the Scientific Foundation SPIROSKI, Skopje Republic of Macedonia Competing Interests: The authors have declared that no
competing interests exis Open Access: This is an open-access article distributed under the terms of the Creative Commons Attribution-

\begin{abstract}
BACKGROUND: Clinical manifestation of coronavirus disease (COVID-19) could be asymptomatic, mild to severe even mortality. Although various hematological complications associated with COVID-19 infection have been reported, the finding of autoimmune hemolytic anemia (AlHA) is a novel case.

CASE REPORT: A 59-year-old woman was admitted to our emergency room because of a 5-day period of fever with cough and shortness of breath. At admission, she was takipnea, jaundice, and had an oxygen saturation of $60 \%$ on room air. Laboratory studies showed hemoglobin $(\mathrm{Hb}) 3.68 \mathrm{~g} / \mathrm{dL}$, high reticulocyte $(14.4 \%)$, and hyperbilirubinemia Chest X-ray showed bilateral pneumonia with positive severe acute respiratory syndrome coronavirus 2 polymerase chain reaction test. Although she got packed red cell (PRC) transfusions in 7 days, her $\mathrm{Hb}$ remained low and bilateral infiltrate still increased. That's why we considered direct Coombs test and it returned positive. AlHA was diagnosed and treatment with hydrocortisone $100 \mathrm{mg}$ IV twice daily was given for the first $72 \mathrm{~h}$. The maintenance dose with methylprednisolone $16 \mathrm{mg}$ twice daily was continued for 7 days admission. Then, $\mathrm{Hb}$ value increased to $11.03 \mathrm{~g} / \mathrm{dL}$
\end{abstract} and she was discharged home without any compliments.

CONCLUSION: In the current epidemiological situation, AlHA needs to be considered as a complication of COVID-19 infection in a patient who presents with jaundice and severe anemia without any underlying chronic disease, which is need blood transfusions, steroid medication use, or blood cancer.

\section{Introduction}

Unexplained pneumonia cases were reported by the People in Republic of China to the World Health Organization on December 31, 2019. This outbreak called coronavirus disease 2019 (COVID-19) that caused by severe acute respiratory syndrome coronavirus 2 (SARSCoV-2) [1]. Indonesian Ministry of Health reported the total number of COVID-19 cases in the world as of July 20, 2020, was confirmed as many as $14,043,176$ cases and infected 215 countries around the world. Of these, 597,583 people were reported dead. The mortality rate for COVID-19 in Indonesia is quite high (4.8\%) when compared to the world average mortality rate of around $4.3 \%$ [2].

SARS-CoV-2 has spike protein which can strongly bound with an angiotensin-converting enzyme (ACE-2) in host cell. Mostly, ACE-2 is found in the lower respiratory tract, small bowel enterocyte, heart, vascular structure, and other parts of the body. That's why this virus called thousand faces disease. The clinical manifestation is vary, could be asymptomatic, mild to severe, even mortality. Diabetes, cardiovascular disease, chronic lung disease, malignancy, immunosuppression, obesity, and elderly are high-risk comorbidities which can make poor prognosis of this infection. Laboratory levels of lymphopenia, thrombocytopenia, and elevated D-dimer levels are associated with severe disease [3], [4].

We report a novel case of Autoimmune Hemolytic Anemia (AIHA) as a complication of COVID-19 infection at our institution, Sanglah General Hospital, Bali, Indonesia. AlHAis a disorder caused by the presence of autoantibodies that attack normal erythrocyte membranes, which triggers the hemolysis process and results in a shortening of erythrocyte age (normal erythrocyte age ranges from 100 to 120 days) [4], [5]. This condition exceeds the capacity of the bone marrow to produce new erythrocytes so that the level of reticulocytes in the blood will increase. The process of hemolysis can occur either inside the blood vessels (intravascular) or outside the blood vessels involving the reticuloendothelial system. The antigen on the erythrocyte membrane is recognized as foreign and destroyed in the spleen, liver, or bone marrow (extravascular) [6].

The incidence of AlHA reaches 1/100,000/year which can occur in all age groups, but the incidence increases with age. Diagnosis of AlHA is confirmed with a positive direct Coombs' test (direct antiglobulin test [DAT]) [7]. 
The mechanism of reducing hemoglobin $(\mathrm{Hb})$ levels in COVID-19 patients is very limited. Liu et al. reported that the presence of spike-CD147 protein in the virus plays a role in the process of viral attachment to erythrocytes which causes the release of $\mathrm{Hb}$ from erythrocytes. The released $\mathrm{Hb}$ will be broken down into heme and globin. It reported that viral proteins such as Orflab, ORF3a, and ORF10 are able to bind to porphyrin in heme, which form a complex and causes the destruction of heme [8]. Angileri et al. also reported that molecular mimicry is thought to be a determinant factor in the incidence of AIHA in COVID-19 infection. Ankyrin-1 (ANK-1), a protein in the erythrocyte membrane, has the same antigenic epitope as the Spike protein in SARS-CoV-2 so that erythrocyte destruction is part of the patient's immune defense mechanism which can cause a decrease in Hb levels [9].

The mechanism underpinning autoimmunity in COVID-19 which can cause hemolytic anemia by autoantibodies has yet to be elucidated. Besides that, corticosteroids are recommended to use in a patient with COVID-19 who are experiencing critical acute respiratory distress syndrome (ARDS). However, its administration is still controversial due to unwanted side effects such as secondary infection, complications of long-term use, and delayed viral load reduction [3]. On the other side, first-line therapy in AlHA cases emphasizes the use of corticosteroids to suppress autoimmunity processes that affect hemolysis [7]. Here, we present a complete response (CR) case of AlHA as a new complication in COVID-19 patient in Sanglah General Hospital, Bali, Indonesia

\section{Case Report}

A previously healthy 59-year-old woman, a shopkeeper, was admitted to our emergency room because of a 5-day period of fever with the cough. She also felt shortness of breath from one a week before admission, then worsen in 5 days. Changing position could not relieve the symptoms. Besides that, she also felt fatigue, nausea, and vomiting. Three days before admission, she also got jaundice in her eye and melena. The patient denied of suffering gall stone, kidney disease, or gastric ulcer before. She also did not have any history of disease, such as asthma, cancer, diabetes mellitus, hypertension, or tuberculosis. There was not any medication which she was consumed regularly.

In the emergency room, she was tachypnea, tachycardia, and had an oxygen saturation of $60 \%$ on room air. Laboratory studies showed $\mathrm{Hb} 3.68 \mathrm{~g} / \mathrm{dL}$ (13.5-17.5 g/dL) with microcytic hypochromic, leukocyte $11.600 / \mu \mathrm{L}(4.100-11.000 / \mu \mathrm{L})$, and high reticulocyte (14\%). The value of SGOT is $106.4 \mathrm{U} / \mathrm{L}(11-27 \mathrm{U} / \mathrm{L})$, SGPT is $60.90 \mathrm{U} / \mathrm{L}(11-34 \mathrm{U} / \mathrm{L})$, ureum $17.7 \mathrm{mg} / \mathrm{dL}$
(8-23 $\mathrm{mg} / \mathrm{dL})$, and creatinine is about $0.79 \mathrm{mg} / \mathrm{dL}(0.5-$ $0.9 \mathrm{mg} / \mathrm{dL}$ ). There was increment in bilirubin (total bilirubin $5.93 \mathrm{mg} / \mathrm{dl}$; direct bilirubin $2.36 \mathrm{mg} / \mathrm{dl}$, and indirect bilirubin $3.57 \mathrm{mg} / \mathrm{dl}$ ). Besides that, prothrombin time/PT is $17.9 \mathrm{~s}(10-14.4 \mathrm{~s})$ and activated partial thromboplastin time/APTT is $48.7 \mathrm{~s}$ (24-36 s). Feritin level as high as $6020 \mathrm{ng} / \mathrm{mL}(13-150 \mathrm{ng} / \mathrm{mL})$ and total iron-binding capacity (TIBC) level is $228 \mathrm{~g} / \mathrm{dL}$ (261$478 \mathrm{~g} / \mathrm{dL}$ ). Other laboratory studies showed serum iron $144.1 \mathrm{~g} / \mathrm{dL}(50-170 \mathrm{~g} / \mathrm{dL})$, alkaline phosphatase $54 \mathrm{U} / \mathrm{L} \quad(42-98 \mathrm{U} / \mathrm{L})$, total protein $7.4 \mathrm{~g} / \mathrm{dL}$ (6.4-8.3 g/dL), globulin 3.5 (3.2-3.7), and gamma-GT $31 \mathrm{U} / \mathrm{L}(7-32 \mathrm{U} / \mathrm{L})$. HBsAg test and Anti-HCV were nonreactive. The chest $\mathrm{X}$-ray showed bilateral pneumonia. Besides that, the polymerase chain reaction (PCR) test SARS-CoV-2 was positive through nasopharyngeal and oropharyngeal swab.

Blood gas analysis reported that she got hypoxemic respiratory failure (type I) with uncompensated metabolic acidosis. Peripheral blood smear showed severe anisopoikilocytosis hypochromic with giant thrombocyte only, another parameter blood smear was normal.

At admission, this patient got packed red cell (PRC) in 3 days and her hemoglobin increase becomes $7.47 \mathrm{~g} / \mathrm{dL}$, but in 2 days later, her $\mathrm{Hb}$ decreases in $6.35 \mathrm{~g} / \mathrm{dL}$. Transfusions were continued in 3 days later, so her $\mathrm{Hb}$ becomes $8.69 \mathrm{~g} / \mathrm{dL}$, but she felt fatigue and became more hypoxic, so she still dependent in oxygen supplementation. Her chest X-ray also showed much more infiltrate addition in both of her lungs than before. Because of this condition and the jaundice was still remained in her eyes, we considered to do serology test to see autoimmunity condition in this patient. Then, the results of direct Coombs test (DAT) were positive, and indirect Coombs test was negative. Hence, the diagnose of this patient was confirmed to be AIHA

During admission, she was given oxygen using face mask, intravenous (IV) fluid drip, cefoperazone 1 g IV twice a day, azithromycin $500 \mathrm{mg}$ oral once daily, hyloquin $200 \mathrm{mg}$ oral twice a day, acetylcysteine 200 mg oral 3 times a day, and Vitamin C 500 mg oral twice a day. Besides that, she got hydrocortisone $100 \mathrm{mg}$ IV twice a day at the first $72 \mathrm{~h}$ after she confirmed as AlHA. She relieved her symptoms such as weakness, pale skin, and tiredness; then, she got a maintenance dose of methylprednisolone $16 \mathrm{mg}$ oral twice a day in the next 7 days of her admission. After this treatment, her $\mathrm{Hb}$ becomes $11.03 \mathrm{~g} / \mathrm{dL}$ and she does not have any compliments so she could discharge home.

\section{Discussion}

The COVID-19 pandemic has caused significant morbidity and mortality. The clinical manifestations of COVID-19 patients have a broad 
spectrum, ranging from symptoms (asymptomatic), mild symptoms, pneumonia, severe pneumonia, ARDS, sepsis, to septic shock [10]. Manifested clinical anemia, many times, have been reported in COVID-19 patients with severe disease [11].

Patient 59-year-old woman, with a history 5-day period of fever with cough, shortness of breath, felt fatigue, and she also got jaundice in her eye. There is no family history with hematology disease. Physical examination was tachypnea, tachycardia, and hypoxia. Laboratory studies showed severe anemia with high reticulocyte, increment in bilirubin, ferritin level, and TIBC level. Serum iron, alkaline phosphatase, total protein, globulin, and gamma GT was normal. The chest X-ray showed bilateral pneumonia. PCR test SARS-CoV-2 was positive through nasopharyngeal and oropharyngeal swab. Direct Coombs test was positive.

This patient is confirmed as COVID-19 based on the symptom in respiratory failure and positive results in PCR Test SARS COV-2. Recommendations from the First International Consensus Meeting reported about diagnostic criteria for AIHA are hemolysis sign accompanied by a positive DAT and exclusion of alternative causes [12]. In this patient, we got a sign of hemolysis such as jaundice, increment of hemolytic markers such as bilirubin and reticulocyte. Besides that, from the blood smear test, we found severe anisopoikilocytosis that shows hemolytic condition. Hence, she was confirmed to be AlHA through the positive result of DAT.

Besides that, her iron blood test showed normal serum iron, increase in ferritin value, and TIBC value was decline which could be excluded iron deficiency anemia. She also did not have any history of chronic disease which is need medication regularly, so there was not any chronic disease or drug that induced her anemia. HBsAg test and anti-HCV were non-reactive, so anemia caused by hepatitis can be ruled out. There was no obvious provoking factor to her AlHA condition and thus it was attributed to her COVID-19 infection, being the first case reported so far in Bali, Indonesia.

Our patient during 3 days of treatment since patient hospitalized, from May 24, 2020, to May 26, 2020 , the patient was given four bags of PRC blood transfusions ( $1.000 \mathrm{ml} \mathrm{PRC})$, the $\mathrm{Hb}$ level increased from $3.68 \mathrm{~g} / \mathrm{dL}$ to $7.47 \mathrm{~g} / \mathrm{dL}$, but the decrease in $\mathrm{Hb}$ levels occurred again on May 28, 2020, to $6.35 \mathrm{~g} / \mathrm{dL}$ with persistent weakness and tightness so that patients still need oxygen supplementation. The patient was again given PRC transfusions from May 29, 2020, to May 31, 2020, as much as five bags of PRC (1.250 ml $\mathrm{PRC})$, with an $\mathrm{Hb}$ level of $8.69 \mathrm{~g} / \mathrm{dL}$; the patient still complained of persistent tightness and chest X-ray evaluation showed additional infiltrates in both lung fields compared to the chest X-ray previously. During treatment, the patient showed no clinical improvement as well as an increase in $\mathrm{Hb}$ levels according to the transfusion target.
Anemia that occurs in patients is suspected to be due to the presence of a hemolysis process caused by autoimmunity so that the patient is subjected to direct Coombs test, and the result was positive. Since the patient is diagnosed with AIHA with COVID-19, the management using $100 \mathrm{mg}$ of hydrocortisone steroid therapy every $12 \mathrm{~h}$ for 3 days intravenously starting on June 01, 2020-June 04, 2020. The patient has experienced improvement after being given steroids both clinically, laboratory, and radiologically so that it is continued by administering methylprednisolone $16 \mathrm{mg}$ every $12 \mathrm{~h}$ orally for 7 days of treatment. When discharged, the patient clinically had no complaints of respiration and laboratory results showed an improvement in $\mathrm{Hb}$ levels, bilirubin levels, and liver function.

AlHA is characterized by the destruction of red blood cells by autoantibodies, but the mechanism underlying the autoimmunity of SARS-CoV-2 infection has yet to be explained. To the best of our knowledge, this is the first case report of COVID-19 with AIHA infection in Indonesia. In another case report, seven patients from six hospitals in France and Belgium reported the emergence of AHAI during COVID-19 infection accompanied by previous comorbid diseases (hypertension, diabetes mellitus, and chronic renal failure). The mean time between the onset of Covid-19 symptoms and the onset of AHAl was 9 days (range 4 and 13 days) [11]

The mechanisms for reducing $\mathrm{Hb}$ levels in COVID-19 patients are very limited, two mechanisms currently reported are the Liu $\mathrm{W}$ and Angileri $\mathrm{F}$ studies in 2020. Liu et al. reported that the presence of spike-CD147 protein in the virus plays a role in the process of viral attachment to erythrocyte digestion and Angillery et al. reported that molecular mimicry ANK-1, a protein in the erythrocyte membrane, has the same antigenic epitope as the Spike protein in SARS-CoV-2 so that erythrocyte destruction as part of the patient's immune defense mechanism can cause a decrease in $\mathrm{Hb}$ levels [8], [9].

Liu et al. recently, it reports that the virus may first infect cells with ACE2 receptors, including immune cells. Immune cells produced antibodies and viral proteins. Antibodies and red blood cells generated immune hemolysis, or red blood cells were infected by Spike-CD147 pathway, by then, $\mathrm{Hb}$ was attached and then attacked produce toxic and inflammatory derivatives. This mechanism because of some viral proteins could combine to the porphyrin to form a complex, respectively. At the same time, orf1ab, ORF3a, and ORF10 proteins could coordinate attack the heme on $\mathrm{Hb}$. Deoxyhemoglobin is more vulnerable to virus attacks than oxidized $\mathrm{Hb}$. The attack will lead to less $\mathrm{Hb}$ to carry oxygen and carbon dioxide. Lung cells are toxic and inflammatory due to derivatives produced by the attack, which eventually resulted in ground glass appearance. Capillaries easily were broken due 
to inflammation. Proteins such as fibrinogen fill the capillaries cracks through the coagulation reaction [8].

Angilleri e.al. reported the hypothesis that molecular mimicry ANK-1, a protein in the erythrocyte membrane, has the same antigenic epitope as the Spike protein in SARS-CoV-2 so that erythrocyte destruction as part of the patient's immune defense mechanism can cause a decrease in $\mathrm{Hb}$ levels. ANK-1 is an erythrocyte membrane protein for red cell differentiation and function, providing the primary connection between the membrane skeleton and the plasma membrane. They found that ANK-1 shares a putative immunogenicantigenic epitope (amino acids LLLQY) with 100\% identity with the SARS-CoV-2 surface glycoprotein named Spike protein. They are established that this epitope is part of Spike's predicted immunogenic epitope 750-SNLLLQYGSFCTQL-763 for B cells using the immune epitope database and analysis resource [9].

Steroid administration in COVID-19 is given in accordance when a hypoxic condition occurs in the patient. Giving anti-inflammatory therapy too early is not recommended because it can inhibit the development of adaptive immune responses and even trigger viral replication [13]. This is in line with research by Lee et al. who reported that administration of corticosteroid therapy early in Coronavirus infection is associated with an increase in plasma viral load and should be avoided [14]. Steroids such as dexamethasone $6 \mathrm{mg}$ given for 10 days indicated only for patients with acute hypoxemic respiratory failure (increased oxygen demand), requires mechanical ventilation, as well as in conditions that support the need for steroids (e.g., asthma with chronic obstructive pulmonary disease [COPD] and COPD exacerbations). Other corticosteroids that can be an option in the equivalent dose are betamethasone oral $6 \mathrm{mg}$, methylprednisolone oral or injection $32 \mathrm{mg}$, and prednisone or prednisolone $40 \mathrm{mg}$ oral [15]. The recommended dose is hydrocortisone $200 \mathrm{mg} / 24 \mathrm{~h}$ or its equivalent, given in conditions of refractory shock or signs of ARDS. The administration of corticosteroid therapy is proven to provide benefits in the development of the patient's condition so that the patient can avoid worsening that requires mechanical ventilation and achieve a CR in conditions of AIHA. Since corticosteroid can make false negative in direct Coombs test (DAT), it suggested that direct Coombs test should be performed before corticosteroid administration.

\section{Conclusion}

To the best of our knowledge, this is the first case report SARS CoV-2 could have triggered AIHA in adult in Bali, Indonesia. Her workup for other etiologies, including other diseases or another viral infection that causes hemolytic condition was unrevealing. During this current COVID-19 pandemic, it is necessary to consider the presence AIHA as new complications in COVID-19 infection. Hence, it is deemed necessary to carry out a DAT to rule out complications of AIHA in COVID-19 patients who present anemia accompanied by evidence of hemolysis to provide comprehensive therapy of the patient.

\section{References}

1. Wu Z, McGoogan JM. Characteristics of and important lessons from the coronavirus disease 2019 (COVID-19) outbreak in China: Summary of a report of 72314 cases from the Chinese Center for disease control and prevention. JAMA. 2020;323(13):1239-42. https://doi.org/10.1001/jama.2020.2648 PMid:32091533

2. Kementerian Kesehatan Republik Indonesia. Info Infeksi Emerging Kementerian Kesehatan RI Update Hingga. Indonesia: Kementerian Kesehatan Republik Indonesia; 2020. Available from: https://covid19.kemkes.go.id/category/situasiinfeksi-emerging/info-corona-virus/\#.X6dwjvkzblU, 20 August 2020.

3. Susilo A. Tim penanganan kasus pasien dengan penyakit infeksi new emerging dan re-emerging disease (PINERE) RSUPN Dr. Cipto mangunkusumo. Coronavirus disease 2019: Review of current literature. J Penyakit Dalam Indones. 2020;7(1):433. https://doi.org/10.7454/jpdi.v7i2.433

4. Huang C, Wang Y, Li X, Ren L, Zhao J, Hu Y, et al. Clinical features of patients infected with 2019 novel coronavirus in Wuhan, China. Lancet. 2020;395:497-506.

5. Longo DL, Kasper DI, Jameson JL, Fauci AS, Hauser SL, Loscalzo J. Harrison's Principles of Internal Medicine. $18^{\text {th }}$ ed. United States: McGraw-Hill; 2012. https://doi. org/10.1111/j.1445-5994.2008.01837.x

6. Sudoyo AW, Setiyohadi B, Alwi I, Simadibrata M, Penyunting SS Buku Ajar IImu Penyakit Dalam. Jakarta: Interna Publishing; 2009. p. 1162.

7. Hill QA, Stamps R, Massey E, Grainger JD, Provan D, Provan D, et al. The diagnosis and management of primary autoimmune haemolytic anaemia. $\mathrm{Br} J$ Haematol. 2017;176(3):395-411. https://doi.org/10.1111/bjh.14478

PMid:28005293

8. Liu W, Li H. COVID-19: Attacks the 1-beta Chain of Hemoglobin and Captures the Porphyrin to Inhibit Human Heme Metabolism. China: Sichuan University of Science and Engineering; 2020. https://doi.org/10.26434/chemrxiv.12120912

9. Angileri F, Legare S, Gammazza AM, Macario EC, Macario AJL, Cappello F. Is molecular mimicry the culprit in the autoimmune haemolytic anaemia affecting patients with COVID-19? Br J Haemotol. 2020;190(2):e92-3. https://doi.org/10.1111/bjh.16883 PMid:32453861

10. World Health Organization. Report of the WHO-China Joint Mission on Coronavirus Disease 2019 (COVID-19). Geneva: World Health Organization; 2020.

11. Lazarian G, Quinquenel A, Bellal M, Siavellis J. Autoimmune haemolytic anaemia associated with Covid-19 infection. 2020. Br J Haematol. 2020;190(1):29-31. PMid:32374906

12. Jager U, Barcellini W, Broome C, Gertz MA, Hill A, Hill QA. Diagnosis and treatment of autoimmune hemolytic anemia in adults: Recommendsations from the first international 
consensus meeting. Blood Rev. 2020;41:1006-48 https://doi. org/10.1016/j.blre.2019.100648

PMid:31839434

13. Rezk NA, Ibrahim AM. Effects of methyl prednisolone in early ARDS. Egyp J Chest Dis Tuberc. 2013;62:167-72. https://doi. org/10.1016/j.ejcdt.2013.02.013

14. Lee N, Chan A, Hui D, Enders KO, Wu A, Chiu R. Effects of early corticosteroid treatment on plasma SARS-associated coronavirus RNA concentrations in adult patients. J Clin Virol. 2004;31(4):304-9. https://doi.org/10.1016/j.jcv.2004.07.006

PMid:15494274

15. Fang X, Mei Q, Yang T, Li L, Wang Y, Tong F. Low-dose corticosteroid therapy does not delay viral clearance in patients with COVID-19. J Infect. 2020;80(1):147-178. https://doi. org/10.1016/j.jinf.2020.03.039

PMid:32283153 